„Śląskie Studia Polonistyczne” 2020, nr 2 (16) ISSN 2353-0928

https://doi.org/10.31261/SSP.2020.16.05

\section{Ananda Devi}

\section{Perkal}

I

Pomimo, że nakłuwam sobie koniuszki palców, atrament nie napływa.

Jakież to było piękne przyzwyczajenie.

Za pierwszym razem stało się to przypadkiem: siedząca dziewczynka

Grzeczna w marszczonej sukience, skrzyżowane nogi, białe buty i

skarpetki, na czole grzywka, bardzo długie włosy

ściśle splecione, policzki pyzate od pieszczot, buzia ściśnięta, Skondensowana, krótki spazm gotowych do płaczu nozdrzy, Polecenie mojej matki, żebym uważała, małe rączki niezręczne niewprawne, lewa trzymająca kwadratowy kawałek surowego

perkalu, prawa igłę nieomal zbyt cienką, żeby była prawdziwa: szyłam.

Ale najpierw trzeba było nawlec igłę. Ślini się nić wilgotnym językiem, żeby zmusić ją do przejścia przez ucho, przez ucho

Szary kot uciekający przed nocą, ucho igielne Szeherezady, Ale nie, mój umysł odciągał mnie zbyt daleko, to była zwykła domowa czynność szycia i oto nić przechodziła, prawie nie drgając, przez mikroskopijną szparkę, przez którą nawet powietrze nie przechodziło,

i zniecierpliwiona, wbiłam igłę w perkal

przez co, nieświadoma, z rozkoszą wbiłam ją w swój pulchny palec wskazujący

Z palca wypłynął czerwony atrament. Cienki, precyzyjny Strumyczek, którym, zafascynowana, po pierwszym krzyku zranionego zaskoczenia, zaczęłam kreślić na tkaninie litery. Wydało mi się to łatwiejsze niż nawlekanie igły i wolne, punkt po punkcie, wyszywanie arabeski na jedwabiu. Mojej matce nie udało się nauczyć mnie ani szycia, ani haftu. Za to jakie piękne słowa przyozdobiły moją pamięć! Długo wyszywałam moją krwią tkaninę marzeń Niestety, w końcu wyczerpałam tych kilka litrów, które mnie wypełniały, więc na próżno, blada i wychudzona, 
przepatrywałam swoje ciało, nie udało mi się z niego wyciągnąć nic poza ciszą.

II

Tego wieczora przechadzałam się w stroju wiosennym, w długiej białej

sukni i kwiecistym kapturku, tak jak to lubią dziewczynki

które nie rosną, w uszach kolczyki w kształcie pszczół

a w kąciku ust rysunek w kształcie kwiatu,

kiedy z daleka zobaczyłam zwierzęcy kształt o bladym spojrzeniu, groteskowo napuszony.

Bałam się potworów i tamten to poznał.

Zbliżył się, powąchał moje dłonie, objawił mi swoje kły i swoją złość. Jego sierść pachniała morzem. Algi

zwisały z jego szyi i pieściły mu boki. Kilka

łez piasku przykleiło się do jego rzęs.

Po chwili jego oddech splótł się z moim

a w jego oczach ujrzałam zwierzęcy lęk.

III

Którejś nocy obudziłam się i zawołałam swoją siostrę imieniem Dinarzade. Uśmiechnęła się, ale zdawało mi się, że czekał nas topór. Muszę nizać swoje opowieści, powiedziałam jej, żeby sporządzić z nich różaniec. Będziesz go nosiła na szyi. Żadne ostrze

nie będzie mogło jej przeciąć.

Od tej pory nocami nie spałam. Musiałam otoczyć

sułtana moimi zdaniami. Opowiadać mu o podróżnych noszących

swoje życie na ramionach: jeśli mnie upuścisz, mówiłoby

im, umrzesz.

Chodź wszędzie ze swoim życiem siedzącym ci na ramionach.

Podobne jest do

starego szkaradnego człowieka, którego uda ściskają ci szyję.

Jego paznokcie zagłębiają się w twoim karku i kłaczek po kłaczku wyrywają ci wszystkie twoje włosy.

Sułtan roześmiał się: spójrz na mnie, pięknego i młodego, czy

sądzisz, że moje

życie jest starym szkaradnym człowiekiem? To kobieta piękna i

dojrzała, a jej sok ma barwę pereł, które ozdabiają jej szyję.

Za nim stary człowiek położył sobie palec na ustach i

dał mi znak, żeby nic nie mówić. Żaden różaniec nie

ochraniał jego szyi.

IV

Ta opowieść - rzekła Szeherezada - jest bardzo piękna.

Opowiedz mi ją - odparł sułtan.

Pewnego dnia, książę przebrany za żebraka -

Dlaczego był przebrany za żebraka? - spytał sułtan. 
Ponieważ, gdy się rodził, jego matka królowa straciła głos Dlaczego straciła głos? - spytał sułtan.

To dlatego, że kiedy królowa miała zaledwie piętnaście lat, uderzyła małą służącą o złotych oczach.

Dlaczego uderzyła służącą? - spytał sułtan.

Ta służąca, która nie była służącą, skradła kalifowi ptaka o bursztynowych piórach, ponieważ był jej kochankiem. Jak kochanek zamienił się w ptaka? - spytał sułtan. Otóż pewnego dnia kochanek, który był księciem przebranym za żebraka... - odpowiedziała Szeherezada.

$\mathrm{V}$

Sny sułtana i potwora pomieszały się.

Księżyc i biała zasłona przekształciły je w stworzenie Dwugłowe. Każde patrzyło w przeciwną stronę, ale ich ciało bliźniaków syjamskich biło tylko jednym sercem.

Dziewczynka słuchała ich. Sułtan mówił o śmierci a potwór o narodzinach. Potwór nosił w sobie małe Ciałko pokryte czerwonym kapturkiem i kochał je. Czekał aż ktoś przyjdzie otworzyć mu brzuch.

Sułtan myślał o kobiecie, której jutro zetnie głowę, i o tej z następnego dnia i z jeszcze następnego i z kolejnego. Długi naszyjnik z kobiecych głów z włosami prostymi lub Kręconymi, ciemnymi i jasnymi, o twarzach tak do siebie podobnych w owym

niepochwytnym spoczynku - klejnocie najrzadszym ze wszystkich, które

kiedykolwiek posiadał - że głowy te, co wieczór, opowiadały jakąś historię.

Był sobie raz...

Once upon a time...

Enn zur dan enn pei...

Dziewczynka obserwowała formę opowiadań i ich proste

Okrucieństwo: tak będę pisać, rzekła nakłuwając sobie

Palec.

Trzy kropelki krwi rozgwieździły się na jej pościeli.

VI

Małe diabełki czuwają. I duże też.

Muślinowa suknia rozsnuwa się kwiatową koroną po stawie, Gdy dłoń za kostkę ciągnie i jeszcze ciągnie. W cieniu Jaskiń olbrzym szlocha zdejmując delikatną skórę Dziewcząt.

Wieczerzajmy, wieczerzajmy, ding dong.

$\mathrm{Na}$ paterze wymieniają się pierzaste pocałunki.

Szpony cię grzebią.

Trzy krople krwi o jasnym śpiewie.

Dla każdego. 
Nie śpij tej nocy dziewczynko: noc ma ci za złe, że jesteś.

Nie pozwól, żeby objęła cię swoją miękką pościelą.

Nie mów jej o czym śnisz.

Nie ujawniaj czerni pod swoimi stopami.

Nie mów o falach i wilkach.

Nie przyznawaj się, że kiedy biegniesz po schodach

Stopnie usuwają ci się spod stóp.

Noc karmi się twoimi lękami.

I, kładąc swoje mroczne usta na twoich,

Wdmuchuje ci je z powrotem, po tysiąckroć rozpamiętane,

Obrzmiałe, zwielokrotnione, spuchnięte,

Za duże na twoje szczupłe ciało.

VIII

Więźniarko mitów, żyjesz na wspak, podążając za ścieżkami i okruchami, łajnem sępów, skałami o rozłożystych

skrzydłach, pamięcią rozsiewaną, by lepiej cię zmylić, cierniami, co zbyt spiesznie wyrastają pod podbiciem twojej stopy, opowieścią o

zadrapaniach na twojej gładkiej jeszcze skórze, echem czarownic ujeżdżających swoje księgi zaklęć, krzykiem grzmotu pożerającym Górę.

Długo jeszcze wsłuchiwała się będziesz w cierpliwość wody

Zanim w niej zanurkujesz.

Twoje warkocze zawsze pętać ci będą dłonie,

a śpiąca opowiadaczka, uwiązana do nici, którą sama

wysnuła ze swej słodkiej śliny

utka więcierz

który ją oplecie

potem ściska, wreszcie przydusza i więzi,

długo po wypowiedzeniu ostatniego słowa,

które wyszło z jej cienistych ust,

rozrywając delikatny perkal.

Przełożył z francuskiego (Percale)

Krzysztof Jarosz 